\title{
Research on the Features and Credit Evaluation Indicator System of Social E-Commerce
}

\author{
Pingfang Yang \\ International Business School \\ Yunnan University of Finance and Economics \\ Kunming, China \\ 93039219@qq.com
}

\begin{abstract}
The combination of social networking and ecommerce has formed a new e-commerce model-social ecommerce. In recent years, with the rapid development of social media, social e-commerce develops quickly. In this paper, we analyze the features of social e-commerce. A new credit evaluation indicator system for social e-commerce is established. The use of the results is favorable for promoting China's social ecommerce to develop healthily and rapidly.
\end{abstract}

Keywords: social e-commerce, social media, credit, indicator

\section{INTRODUCTION}

According to The 44th China Statistical Report on Internet Development issued by China Internet Network Information Center (CNNIC), by the end of June 2019, the scale of netizens reached 8.54 billion, increasing $6.59 \%$ compared with the same period of 2018, and the rate of Internet popularization is $61.2 \%$. The scale of mobile phone netizens reached 8.47 billion, increasing $7.50 \%$ compared with the same period of last year, and $99.1 \%$ of the netizens surf the Internet by means of mobile phone. The scale of China's online shopping users reached 6.39 billion, increasing $12.3 \%$ year-on-year, and accounted for $74.8 \%$ of the netizens. Among them, online shopping users through mobile phone reached 6.22 billion, increasing $11.6 \%$ year-on-year, which accounted for $73.4 \%$ of the mobile netizens. The market of online shopping keeps developing at a high speed, and the sinking market, cross-border e-commerce and mode innovation provide new growth drivers for online shopping market [1]

In recent years, e-commerce in China develops rapidly. The 2018 China E-Commerce Development Index Report showed that the amount of online transaction in China in 2018 reached 31.63 trillion yuan, increasing $8.5 \%$ compared with the same period of 2017. The 2018 China B2C E-commerce Market Monitoring Report published by iiMedia Research showed that the scale of mobile e-commerce users in China had been increasing steadily and reached 5 billion in 2018. The scale is estimated to reach 5.46 billion by the end of 2019 [2].

The data published by Ministry of Commerce of the P.R.China showed that, by the end of the first half of 2019, online retail sales in China reached 4.82 trillion yuan, increasing $17.8 \%$ compared with the same period of last year.

According to an analysis of business-to-business sales by B2BecNews, a publication of Digital Commerce, 2018 represented a milestone for commercial transition in America: for the first time U.S. companies made more of their sales to businesses electronically than through traditional purchasing methods [3].

The 43th China Statistical Report on Internet Development showed that by the end of December, 2018, the proportion of users of three types of social media, i.e. Wechat friends circle, QQ space and micro-blog, are $83.4 \%, 58.8 \%$ and $42.3 \%$ respectively [4]. According to A Global Perspective of Mobile Commerce (2017) published by Interactive Advertising Bureau(IAB), $60 \%$ of the consumers often look for new goods and service through social media, and $36 \%$ of the consumers like to share their experiences of mobile shopping on the Internet [5]. The 2018 Social Commerce Survey presented by SUMO Heavy Industries showed that, for a majority of shoppers, social media's influence isn't limited to the discovery stage. $58 \%$ of respondents say social media influences a purchasing decision, even if it's not where the product or service is discovered. Compared to the $45 \%$ that reported the same in 2016, it's clear that social media continues to be a growing opportunity for retailers [6].

Due to the wide use of Wechat circle and micro-blog, and rapid development of social media, the combination of social networking and e-commerce has formed social e-commerce. Based on Web2.0, social e-commerce is a new model of ecommerce which uses social media to support trade parties to transit and share information, and recommend and evaluate products or services, so as to promote the transaction of products or services[7]. The concept of social e-commerce is first put forward by Yahoo in 2005. Compared with traditional e-commerce, social e-commerce has the obvious property of society such as users' producing contents, user interaction, social network, interesting driven and word-of-mouth marketing.

Social e-commerce uses the sharing and interaction among users to promote the consumers to shop online. Because of the virtual, anonymous, cross regional characteristics of ecommerce, there are credit risks such as network cheating. A Global Perspective of Mobile Commerce (2017) published by Interactive Advertising Bureau (IAB) showed that $44 \%$ of the consumers regard trust as an obstacle to shop online [5]. The survey of SUMO Heavy Industries showed that security and privacy concerns continue to hinder social commerce, $71 \%$ cite 
security as a major concern, followed by privacy at $65 \%$ and legitimacy at $64 \%$ [6].

Compared with traditional e-commerce, social e-commerce is more virtual and stresses the cooperation of buyer and seller, so credit management of the sellers is more important. In order to solve the problem of credit, it is critical to establish credit evaluation indicator system for social e-commerce.

At present, scholars mainly study the credit or reputation problems in traditional e-commerce, few researches are focused on the credit or reputation problems in social ecommerce. R.A. Malaga points out six problems of existing reputation management systems and suggests some solutions [8]. Considering the time and the value of the transaction, Song Guangxing and Cao Chunfang use the method of weighted average to improve the existing online reputation aggregating approaches used in the websites [9]. Wei Chuang, Yu Zhaoji and Chen Xiaonan propose a social e-commerce online reputation formation model and community state-introduced model. A system dynamics trend simulation has been run to capture the relationship among the sellers, buyers, social ecommerce platforms and external environment to obtain an online reputation [10].

In recent years, more and more researchers begin to concern about social e-commerce. Many scholars discuss the factors influencing users to choose social e-commerce. Claudia Maia, Guilherme Lunardi, Andre Longaray and Paulo Munhoz analyze the main factors and characteristics (personal or related to the purchased products) that influence consumers on their participation in social commerce, either by purchasing, recommending or continuing to use the website [11]. Ali Sahabi Yusuf, Ab Razak Che Hussin and Abdelsalam H. Busalim develop a comprehensive model to investigate the influence of electronic word of mouth (eWOM) engagement on consumer purchase intention in s-commerce [12]. Chen Meng explores the impact of the quantity, quality and structure of contradictory online reviews on consumers' E-purchase intention [13]. Liu Chao, Bao Zheshi and Zheng Chuiyong employ the stimulus-organism-response (S-O-R) model to explore how consumers' purchase intention can be influenced from aspects of trust, argument quality of peer-generated contents, and social presence [7]. Lin Jiabao, Li Lei, Yan Yanmei and Ofir Turel develop a theoretical model that explains the indirect effects of social support from friends on social commerce intentions, as mediated through the relational aspects that potential buyers develop with sellers [14]. Zaryab Sheikh, Liu Yezheng, Tahir Islam, Zahid Hameed and Ikram Ullah Khan investigate the influence of social commerce constructs (SCCs), social support and relationship quality on social commerce intentions, which lead to use behavior of social networking sites for social commerce [15].

Yang Jinbi, Sia Choon Ling, Liu Libo and Chen Huaping investigate the differences in motivations between different user types of social commerce sites: sellers and buyers, and the impact on social commerce [16]. Samira Farivar, Ofir Turel and Yuan Yufei examine the role of social factors such as trust toward site members in determining users' trust and risk evaluations, and the role of social commerce use habit in attenuating users' rational risk and trust considerations for developing purchase intentions [17].

Liu Hong and Zhang Xiaojing analyze the research status of social e-commerce from four aspects, i.e. user's behavior, management, technology support and information service [18]. Zong Qianjin argues that definition, evolution, business model, web design, user acceptance and user buying intention/behavior are the main research fields of social commerce [19].

Credit management problems in social e-commerce are more complicated than that in traditional e-commerce. As the sociality degree of e-commerce becomes higher and higher, traditional modes of credit evaluation are no longer applicable because they have not considered social indicator. The credit evaluation system should be improved and perfected.

\section{FEATURES OF SOCIAL E-COMMERCE}

Because different social e-commerce platforms are much different in the relationship of users, market segmentation, communication channels, core business, use purpose and profit mode, different types of social e-commerce have different features. However, social e-commerce generally has four features, i.e. sociality, interactivity, publicity and commerciality.

\section{A. Sociality}

Just as the name implies, social e-commerce has strong sociality. Users which have common hobbies or the same purchasing purpose will pay attention to certain goods and go together. In traditional e-commerce, the seller attracts users by sending them the information about products and service. But in social e-commerce, the seller adds the social sharing mode to ensure the interaction among users and between users and itself At the same time, users can forwardly share the information of products and service. In other words, in social e-commerce, users are not only the producers of information, but also the disseminators of information.

\section{B. Interactivity}

One of the characteristics of social e-commerce is that the consumers can interact before shopping, during shopping and after shopping. For example, the users can understand certain goods in social platforms before they purchase it. The information about the goods may come from the sharing of their network friend, or from the recommendation of the seller. After the users get the information, they assess their interests in the goods, or inquire about the goods through online customer servers if they have any questions. In such way, they can reduce the risk of shopping activity and their worries. Meanwhile, users may look up the evaluation about the goods of other consumers before they buy it, so as to directly understand the quality of the product and the degree of satisfaction of customers. After the users buy the goods, they can express their opinions on the platform in terms of their shopping experience. From the viewpoint of word of mouth (WOM), these comments will be helpful to other users' shopping decision. All these are interactions. Compared with traditional e-commerce, social e-commerce pays more attention to the collaboration between the buy and the seller for good 
customer relationship, and pays more attention to two-way communication.

\section{Publicity}

The publicity of social e-commerce decides the realization of interaction. The seller should actively put the information about the goods and other consumers' comments on the goods on e-commerce platform for free use. Users can cite the information on the platform according to their interests or unlimitedly and conveniently recommend them to other people. The information and evaluation should be true and objective.

\section{Commerciality}

Social e-commerce is a kind of transaction. So the buy and the seller take what they want and try their best to achieve winwin situation in the process of this transaction. In order to develop sustainably for a long time, the seller will first consider the consumers' shopping intention. Compared with traditional e-commerce, social e-commerce changes the management of material to that of people. Moreover, it changes the profit mode depending only on business into creating value by relationship network.

\section{ESTABLISH THE CREDIT EVALUATION INDICATOR SYSTEM FOR SOCIAL E-COMMERCE}

At present, credit evaluation indicators in e-commerce website focus mainly on goods, service and logistics. Such evaluation method is too simple and do not consider social indicator. In this paper, based on traditional e-commerce website, we consider the feature of sociality and give a set of indicators to evaluate the seller' $\mathrm{s}$ credit in social e-commerce. See TABLE I

TABLE I . CREDIT EVALUATION INDICATOR SYSTEM FOR SOCIAL E-COMMERCE

\begin{tabular}{|c|c|c|}
\hline \multirow{10}{*}{$\begin{array}{c}\text { Credit } \\
\text { evaluation } \\
\text { of the } \\
\text { seller }\end{array}$} & $\begin{array}{l}\text { First-level } \\
\text { indicators }\end{array}$ & Second-level indicators \\
\hline & \multirow[b]{3}{*}{$\begin{array}{c}\text { Commodity } \\
\text { situation } \\
X_{1}\end{array}$} & $\begin{array}{l}\text { Quality of the commodity } \\
X_{11}\end{array}$ \\
\hline & & $\begin{array}{l}\text { Price of the commodity } \\
\qquad X_{12}\end{array}$ \\
\hline & & $\begin{array}{c}\text { Degree of correspondence } \\
\text { between the commodity and } \\
\text { that described on the network } \\
\text { (e.g. specification, color of the } \\
\text { commodity) } \\
X_{13}\end{array}$ \\
\hline & \multirow{3}{*}{$\begin{array}{c}\text { Service of } \\
\text { the seller } \\
\quad X_{2}\end{array}$} & $\begin{array}{c}\text { Pre-sale Service } \\
X_{21}\end{array}$ \\
\hline & & $\begin{array}{c}\text { After-sale service } \\
X_{22}\end{array}$ \\
\hline & & $\begin{array}{c}\text { Fulfillment of other service } \\
\text { promised } \\
X_{23}\end{array}$ \\
\hline & \multirow{3}{*}{$\begin{array}{c}\text { Logistics } \\
\text { service } \\
\quad X_{3}\end{array}$} & $\begin{array}{c}\text { Package of Commodities } \\
\qquad X_{31}\end{array}$ \\
\hline & & $\begin{array}{c}\text { Speed of delivering } \\
\text { Commodities } \\
X_{32}\end{array}$ \\
\hline & & $\begin{array}{c}\text { Attitude of distribution } \\
\text { personnel } \\
X_{33}\end{array}$ \\
\hline
\end{tabular}

\begin{tabular}{|c|c|c|}
\hline & $\begin{array}{c}\text { Information sharing in } \\
\text { Wechat circle } \\
X_{41}\end{array}$ \\
\cline { 3 - 3 } & $\begin{array}{c}\text { Degree of } \\
\text { Sociality }\end{array}$ & $\begin{array}{c}\text { Information sharing in micro- } \\
X_{4}\end{array}$ \\
& blog \\
& $X_{42}$ \\
\cline { 3 - 3 } & Information sharing in other \\
& social platform \\
& $X_{43}$
\end{tabular}

Here, based on the indicators for evaluating the seller's credit in traditional e-commerce, i.e. goods, service and logistics, we further subdivide these indicators into secondlevel indicators in order to make it convenient to evaluate for the consumers. In this way, the credit score of the seller will be more real and reliable.

After establishing credit evaluation indicator system for social e-commerce, we can choose certain method to evaluate the credit of the seller, such as Analytic Hierarchy Process (AHP), fuzzy comprehensive evaluation, and so on.

The 2018 China B2C E-commerce Market Monitoring Report by iiMedia Research showed that users of B2C ecommerce increasingly pursue quality life as their income raise. These users pay more attention on the quality of commodities, and they also mind the price of commodities. So they pursue the commodities with higher cost performance. According to this fact, when we assess the credit of the seller in $\mathrm{B} 2 \mathrm{C}$ ecommerce, we should give higher weights to two indicators reflecting commodity, i.e. quality situation of the commodity and price of the commodity.

Sharing and recommending is the soul of social network. For certain commodity, the more a consumer shares positive information, the more trustworthy this commodity is. Therefore, we use information sharing in Wechat circle, in micro-blog and in other social platform to reflecting the degree of sociality of a seller in social e-commerce.

\section{CONCLUSIONS}

With the rapid development of electronic commerce, people's traditional purchasing mode has been changed. Technology is no longer the bottleneck of e-commerce, and credit is the major environmental factor impacting on ecommerce development. Social e-commerce is a new ecommerce mode with the rise of social networks. Social ecommerce uses social media as a communication channel, and takes advantage of network interactions, generated contents by the user and other ways to support the user's purchasing behavior. Social e-commerce pays much more attention to the influence of the product and its brand than to the sale of this product. Social e-commerce will be the trend of e-commerce development. In this paper, the author analyzes four features of social e-commerce, and puts forward a set of indicators to evaluate the credit of the seller in social e-commerce. For further research, one can study the methods to assess the credit of the seller in social e-commerce based on the indicator system proposed in this paper. In the calculation of comprehensive credit score of a seller after many times of transaction, it is more scientific and rational to consider the value of a transaction, the time of rating and the credit score of the rater. 


\section{ACKNOWLEDGMENT}

This research was supported by the National Natural Science Foundation of China under Grant 71362016.

\section{REFERENCES}

[1] 1] CNNIC. The 44th China Statistical Report on Internet Development [R]. 2019, 8. (In Chinese).

[2] [2] iiMedia Research: The 2018 China B2C E-commerce Market Monitoring Report. http://www.100ec.cn/detail--6481886.html.

[3] [3] B2BecNews. The 2019 U.S. B2B E-commerce Market Report. http://www.100ec.cn/detail--6515052.html.

[4] [4] CNNIC. The 43th China Statistical Report on Internet Development [R]. 2019, 2. (In Chinese)

[5] [5] IAB. A Global Perspective of Mobile Commerce, 2017. http://www.100ec.cn/detail--6413639.html.

[6] [6] SUMO Heavy Industries. The 2018 Social Commerce Survey. http://www.199it.com/archives/779601.html.

[7] [7] Liu Chao, Bao Zheshi, and Zheng Chuiyong. Exploring consumers' purchase intention in social commerce-An empirical study based on trust, argument quality, and social presence. Asia Pacific Journal of Marketing and Logistics, Vol. 31, 2019, No. 2, pp. 378-397.

[8] [8] Malaga R A. Web-based reputation management systems: problems and suggested solutions[J]. Electronic Commerce Research, 2001, No.1 : 403-417.

[9] [9] Song Guangxing, and Cao Chunfang. Research on the online reputation aggregating approaches and the customized recommendation. Forecast, Vol. 28, 2009, No.5:55-58. (In Chinese).

[10] [10] Wei Chuang, Yu Zhaoji, and Chen Xiaonan. Research on social ecommerce reputation formation and state-introduced model. Kybernetes, Vol.46, 2017, No.6, pp. 1021-1038.
[11] [11] Claudia Maia, Guilherme Lunardi, Andre Longaray and Paulo Munhoz. Factors and characteristics that influence consumers participation in social commerce. Revista de Gestão,Vol. 25, 2018, No. 2, pp. 194-211.

[12] [12] Ali Sahabi Yusuf, Ab Razak Che Hussin, and Abdelsalam H. Busalim. Influence of e-WOM engagement on consumer purchase intention in social commerce. Journal of Services Marketing, Vol.32, 2018, No.4:493-504.

[13] Chen Meng. Research about the influence of contradictory online reviews on consumer e-purchase intention. Journal of the Postgraduate of Zhongnan University of Economics and Law. 2016, No.6:68-74. (In Chinese).

[14] Lin Jiabao, Li Lei, Yan Yanmei, and Ofir Turel. Understanding Chinese consumer engagement in social commerce-The roles of social support and swift guanxi. Internet Research, Vol. 28, 2018, No. 1, pp. 2-22.

[15] Zaryab Sheikh, Liu Yezheng, Tahir Islam, Zahid Hameed, and Ikram Ullah Khan. Impact of social commerce constructs and social support on social commerce intentions. Information Technology \& People, Vol. 32, 2019, No. 1, pp. 68-93.

[16] Yang Jinbi, Sia Choon Ling, Liu Libo, and Chen Huaping. Sellers versus buyers: differences in user information sharing on social commerce sites. Information Technology \& People, Vol. 29, 2016, No. 2, pp. 444-470.

[17] Samira Farivar, Ofir Turel, and Yuan Yufei. A trust-risk perspective on social commerce use: an examination of the biasing role of habit. Internet Research, Vol. 27, 2017, No. 3, pp. 586-607.

[18] Liu Hong, and Zhang Xiaojing. Analysis on research status of social ecommerce in our country-based on CNKI literature research. Journal of Modern Information, Vol. 37, 2017, No.2: 171-177.(In Chinese).

[19] Zong Qianjin. A review of social commerce research. Journal of Intelligence, Vol.32, 2013, No.10: 117-121.(In Chinese). 